\title{
MAKE-APPS berbasis android untuk mendukung pembelajaran bagi peserta didik mata pelajaran kearsipan
}

\author{
Rakhmadanti Tiarizki Fitra, I Nyoman Suputra* \\ Universitas Negeri Malang, Jl. Semarang No. 5 Malang, Jawa Timur, Indonesia \\ *Penulis korespondensi, Surel: nyoman.suputra.fe@um.ac.id
}

Paper received: 1-4-2021; revised: 22-4-2021; accepted: 29-4-2021

\begin{abstract}
Abstrak
Perkembangan ilmu pengetahuan dan teknologi telah mempengaruhi penggunaan media pembelajaran dimana guru dituntut untuk kreatif memanfaatkan teknologi secara optimal. Oleh karena itu, penelitian ini bertujuan untuk menghasilkan produk media pembelajaran mobile learning berbasis android pada mata pelajaran kearsipan kelas X. Penelitian dan pengembangan ini menggunakan model Research and Development Borg and Gall yang telah dimodifikasi disesuaikan dengan kebutuhan penelitian. Teknik analisis data yang digunakan adalah teknis analisis data kuantitatif dan kualitatif. Hasil penelitian dan pengembangan ini adalah media pembelajaran mobile learning berbasis android pada mata pelajaran kearsipan yang diberi nama MAKE-APPS yang telah dinyatakan sangat valid dan layak digunakan dalam pembelajaran kearsipan oleh validasi ahli media dan validasi ahli materi. Sehingga dapat disimpulkan bahwa media pembelajaran mobile learning berbasis android MAKE-APPS layak dan efektif digunakan sebagai media pembelajaran bagi peserta didik pada mata pelajaran kearsipan di kelas X.
\end{abstract}

Kata kunci: penelitian dan pengembangan; media pembelajaran; mobile learning; android; kearsipan.

\section{Pendahuluan}

Semakin pesatnya perkembangan ilmu pengetahuan dan teknologi berdampak pada bidang pendidikan (Hrynko, 2019), (Fajriah \& Churiyah, 2016), (Buyukbaykal, 2015). Upaya pembaharuan kurikulum pendidikan dan pemenuhan fasilitas teknologi dilakukan pemerintah untuk meningkatkan kualitas pengajaran dan pembelajaran di sekolah (Buabeng-Andoh, 2012). Implementasi pendidikan yang awalnya menggunakan metode tradisional atau konvensional menjadi terintegrasi dengan teknologi (Hrynko, 2019). Penggunaan media pembelajaran menjadi terpengaruh, guru dituntut untuk kreatif dalam kegiatan belajar mengajar dengan memanfaatkan teknologi secara optimal (Fajriah \& Churiyah, 2016). Dengan adanya kemajuan teknologi informasi dan komunikasi maka guru dalam memberikan materi pelajaran harus mengikuti kemajuan tersebut (Nurrita, 2018).

Media pembelajaran sendiri memegang peran penting dalam proses pembelajaran dimana media pembelajaran mampu membantu guru dalam menyampaikan materi yang diajarkan (Ramdhani \& Muhammadiyah, 2015). Selain itu, penggunaan media pembelajaran juga diharapkan mampu meningkatkan pemahaman siswa terkait materi yang diajarkan guru (Fajriah \& Churiyah, 2016). Media pembelajaran juga dapat dijadikan sebagai alat bantu pada proses belajar dalam rangka komunikasi interaksi guru dan siswa dalam proses pembelajaran (Khairani, 2016). Media pembelajaran saat ini mulai beragam mengikuti perkembangan ilmu pengetahuan dan teknologi yakni media pembelajaran yang berbasis elektronik dapat dijadikan sebagai alternatif pembelajaran pada saat melaksanakan kegiatan pembelajaran dan salah satunya yaitu mobile learning. Penggunaan media pembelajaran mobile learning berbasis android diharapkan memudahkan peserta didik dalam memahami materi pelajaran yang

This work is licensed under a Creative Commons Attribution-ShareAlike 4.0 International License. 
dikemas menggunakan media smartphone sehingga interaksi antara guru dan peserta didik tidak terhambat oleh jarak dan waktu (Nur N. S and Sutarni, 2017; Purwanto and Ramadhan, 2017). Penggabungan antara materi dengan penggunaan media teknologi dapat memungkinkan pembelajaran menjadi lebih luas dan cepat (Bernacki et al., 2020).

Media pembelajaran yang dikembangkan dalam penelitian ini yaitu mobile learning berbasis android. Media ini disajikan dalam bentuk aplikasi mobile yang dapat diinstall pada smartphone android peserta didik masing-masing. Media ini juga didesain dengan menarik yang dilengkapi dengan gambar, materi, video pembelajaran serta soal evaluasi yang hasilnya dapat diketahui secara langsung oleh peserta didik dan secara otomatis terkirim melalui E-mail yang sudah terintegrasi dengan media sehingga guru dapat mengetahui pemahaman peserta didik melalui soal evaluasi yang telah dikerjakan.

Beberapa penelitian sebelumnya yang juga membahas tema ini adalah penelitian yang dilakukan oleh (Sari, dkk, 2019; Rahmat, dkk, 2019; Suprianto, dkk, 2019; Khomarudin dan Efriyanti, 2018; Alhafidz dan Hariyono, 2018; Praseptiawan, dkk, 2018; Irawan dan Rww, 2018; Liliarti dan Kuswanto, 2018; Cahyana, dkk, 2018; Taufiq, dkk, 2017) . Berdasarkan penelitian-penelitian tersebut dapat disimpulkan bahwa pengembangan media pembelajaran mobile learning berbasis android dikatakan layak untuk dikembangkan dan digunakan dalam kegiatan belajar sebagai sumber belajar, dan juga dapat membentuk peserta didik dapat belajar lebih efektif dan efisien untuk melatih keterampilan proses belajar yang baik.

Namun, berdasarkan hasil observasi dan wawancara dengan guru mata pelajaran kearsipan kelas X OTKP diperoleh informasi bahwa kurikulum yang digunakan di sekolah yaitu kurikulum 2013 revisi, dan dalam proses pembelajaran pada mata pelajaran kearsipan guru masih menggunakan media konvensional seperti Powerpoint dan untuk bahan ajar yang digunakan yaitu buku paket belajar, dan bisa mencari materi tambahan melalui internet. Dalam kegiatan pembelajaran guru hanya memberikan materi dalam bentuk slide Powerpoint, kemudian peserta didik diminta untuk mempelajari materinya. Sehingga terkadang peserta didik belum memahami sepenuhnya mengenai materi yang sedang dipelajari. Disini guru dalam kegiatan pembelajaran juga menggunakan metode ceramah sehingga membuat peserta didik cepat bosan dan kurang memahami materi pembelajaran yang disampaikan. Oleh karena itu, berdasarkan permasalahan tersebut peneliti mengembangkan media pembelajaran $M$ Learning berbasis android yang didesain dengan menarik dan akan digunakan pada mata pelajaran kearsipan. Media pembelajaran yang dikembangkan peneliti diharapkan mampu menunjang pembelajaran peserta didik. Dengan media ini juga diharapkan peserta didik termotivasi dalam mengikuti kegiatan belajar mengajar pada mata pelajaran kearsipan, selain itu peserta didik juga lebih fleksibel dalam belajar dimana saja dan kapan saja tanpa adanya batasan ruang dan kondisi. Dan juga bisa memberikan hal baru dalam metode mengajar bagi seorang guru, agar tidak selalu dengan metode ceramah yang membuat peserta didik terkadang bosan. 


\section{Metode}

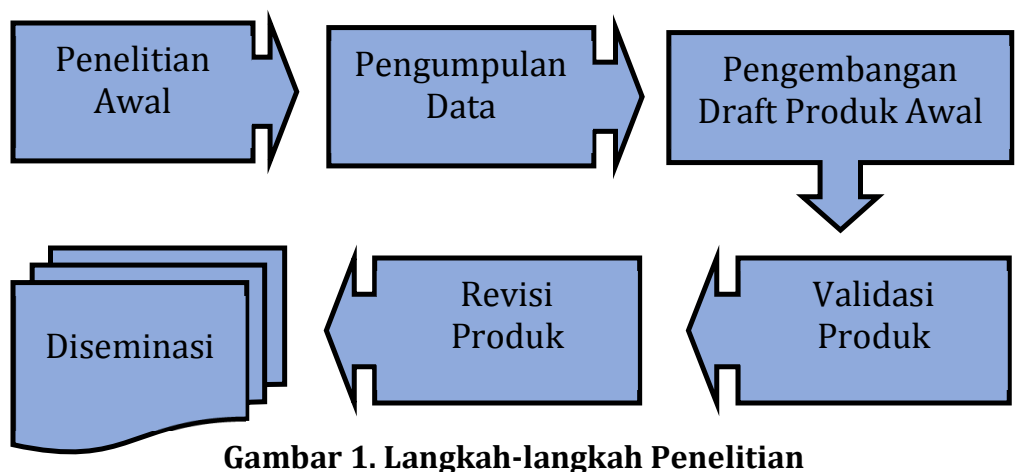

Penelitian ini menggunakan model Research and Development (R\&D) hasil adaptasi Borg and Gall yang telah dimodifikasi menjadi enam langkah untuk mempersingkat waktu dan keterbatasan biaya (Mastumasari et al., 2017; Rahmat et al., 2019). Selain itu, peneliti juga merasa bahwa tujuan penelitian ini yaitu untuk menghasilkan produk media pembelajaran mobile learning berbasis android dan untuk mengetahui kelayakan media pembelajaran mobile learning berbasis android yang telah dikembangkan melalui validasi ahli media dan ahli materi.

Langkah pertama, peneliti melakukan penelitian awal terkait dengan potensi dan permasalahan yang terjadi di sekolah tempat penelitian dan juga kegiatan pembelajaran pada mata pelajaran Kearsipan kelas X melalui wawancara. Langkah kedua, peneliti melakukan perencanaan terkait media yang akan dikembangkan. Langkah ketiga, peneliti melakukan pengembangan produk awal media pembelajaran yang akan dikembangkan dan dapat menjadi solusi atas permasalahan yang ditemukan pada langkah pengumpulan informasi penelitian awal serta mulai membuat media pembelajaran sesuai rancangan yang telah ditentukan pada langkah sebelumnya. Langkah keempat, media yang telah dikembangkan peneliti diuji kelayakannya oleh validator ahli, yakni dua ahli media dan dua ahli materi. Langkah kelima, produk media yang telah divalidasi atau diuji kelayakannya kemudian dilakukan revisi berdasarkan masukan, saran dan kritik yang diberikan oleh para validator pada lembar angket penilaian ahli media dan ahli materi. Langkah keenam, produk yang telah direvisi kemudian diimplementasikan atau didistribusikan kepada guru maupun peserta didik kelas X.

Data yang dihasilkan pada penelitian ini meliputi data kuantitatif dan kualitatif. Data kuantitatif diperoleh berdasarkan data hasil validasi ahli media dan hasil validasi ahli materi. Sedangkan data kualitatif diperoleh melalui kritik dan saran dari validator ahli media dan validator ahli materipada lembar validasi atau angket.

\section{Hasil dan Pembahasan}

Produk yang dihasilkan dalam penelitian dan pengembangan ini adalah media pembelajaran mobile learning berbasis android pada mata pelajaran kearsipan. Produk media pembelajaran mobile learning ini diberi nama MAKE-APPS (Media Pembelajaran Kearsipan dalam Bentuk Aplikasi). Adapun menu dalam media ini akan dijelaskan melalui Gambar 2 berikut ini: 


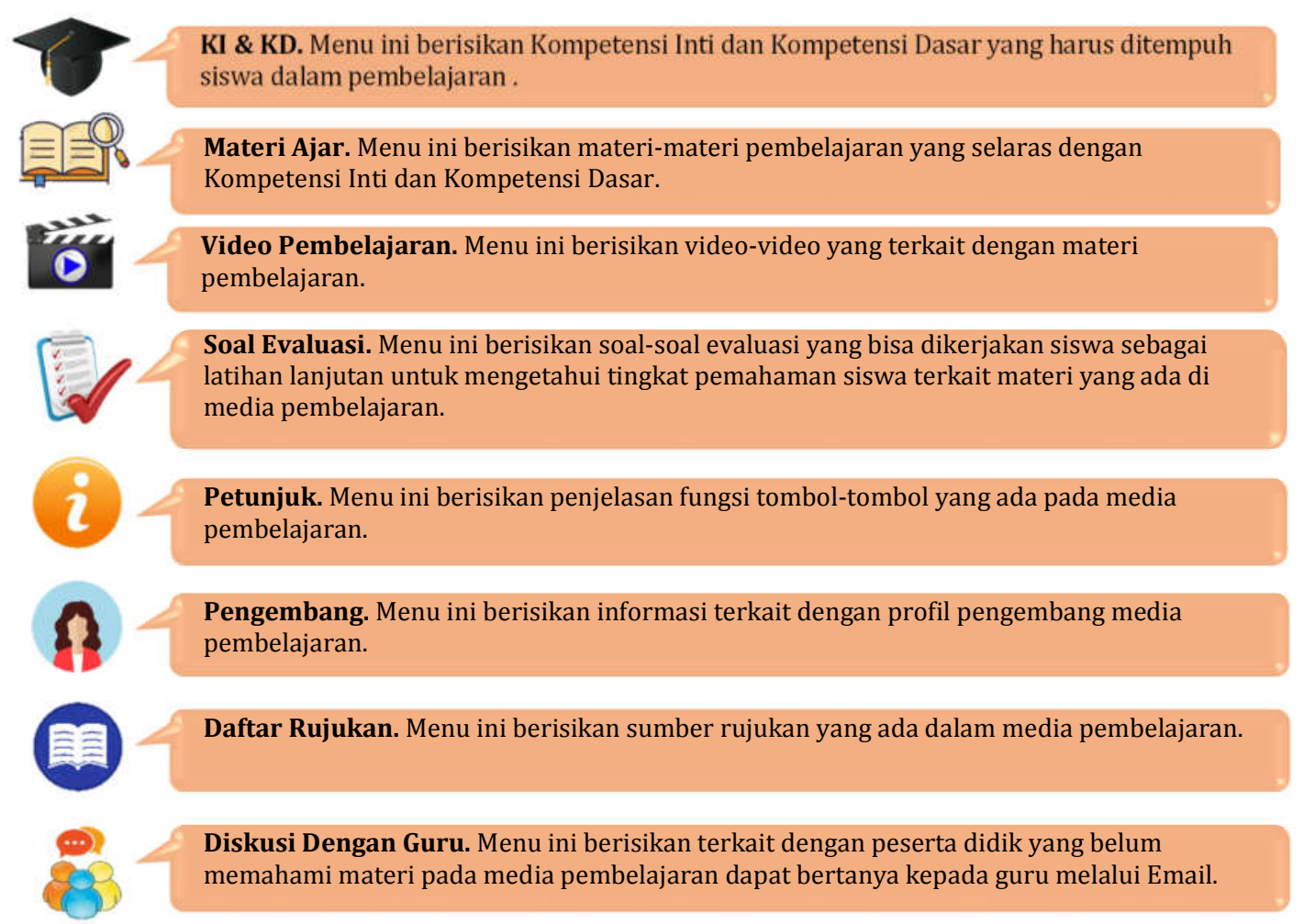

\section{Gambar 1. Menu-menu dalam media pembelajaran MAKE-APPS}

Setelah berada di "Halaman Menu", pengguna dapat menuju Halaman Petunjuk seperti pada Gambar 3 yang berisi petunjuk menu dan tombol yang tersedia.
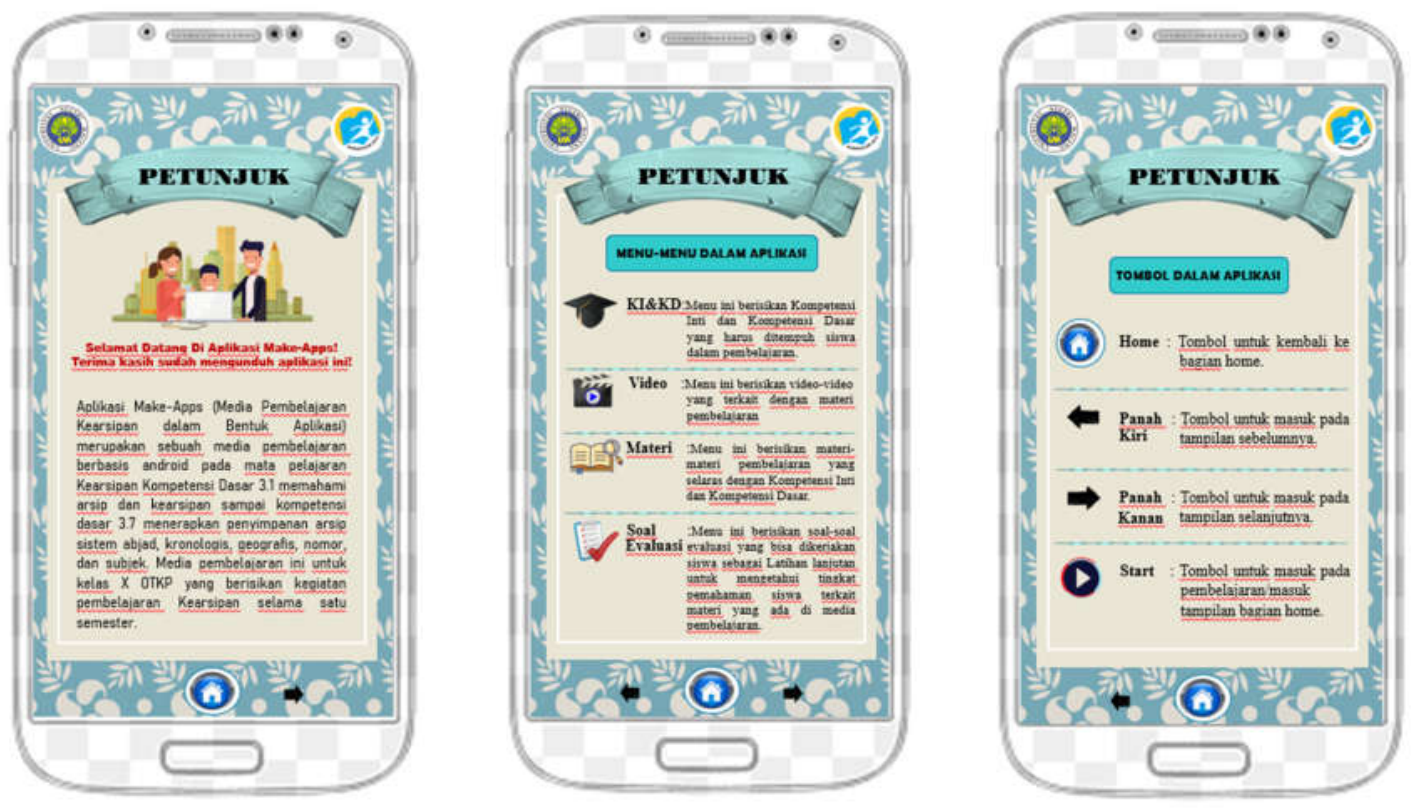

Gambar 3. Petunjuk menu aplikasi MAKE-APPS 
Hasil validasi media pembelajaran mobile learning MAKE-APPS oleh ahli media dan ahli materi secara keseluruhan disajikan dalam Tabel 1 berikut ini:

Tabel 1. Data hasil validasi keseluruhan

\begin{tabular}{clcc}
\hline No & Validasi & Persentase & Kriteria Kevalidan \\
\hline 1 & Ahli Media I & $98,94 \%$ & Sangat Valid \\
\hline 2 & Ahli Media II & $97,89 \%$ & Sangat Valid \\
\hline 3 & Ahli Materi I & $98 \%$ & Sangat Valid \\
\hline 4 & Ahli Materi II & $97 \%$ & Sangat Valid \\
\hline & Rata-Rata & $97,95 \%$ & Sangat Valid \\
\hline
\end{tabular}

Table used by permission (CFitra, Rakhmadanti Tiarizki. 2021. Data hasil validasi keseluruhan.

Berdasarkan Tabel 1 diatas, diketahui bahwa rata-rata persentase validasi secara keseluruhan sebesar 97,95\%, sehingga dapat disimpulkan bahwa media pembelajaran yang dikembangkan peneliti yakni MAKE-APPS dinyatakan "Sangat Valid" dan dapat digunakan pada mata pelajaran kearsipan di SMK Muhammadiyah 5 Kepanjen Malang. Hal tersebut senada dengan penelitian sebelumnya bahwa hasil validasi, ahli materi, ahli media dan uji coba kelompok kecil dijadikan dasar penentuan apakah media pembelajaran yang dikembangkan layak atau tidak digunakan dalam pembelajaran (Nurwijayanti et al., 2019), (Lubis \& Ikhsan, 2015), (Irawan \& Djatmika, 2018).

Kelayakan media pembelajaran mobile learning MAKE-APPS didasari dengan kemenarikan desain tampilan, kemenarikan penyajian materi, dan ketepatan konsep penyajian materi pada media pembelajaran (Muyaroah dan Fajartia, 2017), (Ulfa et al., 2017), (Siregar et al., 2017). Media pembelajaran mobile learning MAKE-APPS menyajikan menu diskusi dengan guru yang terkait dengan peserta didik yang belum memahami materi pada media pembelajaran dapat bertanya kepada guru melalui E-mail yang sudah terintegrasi pada media pembelajaran. Tampilan menu diskusi dengan guru dapat dilihat pada Gambar 4 berikut ini:

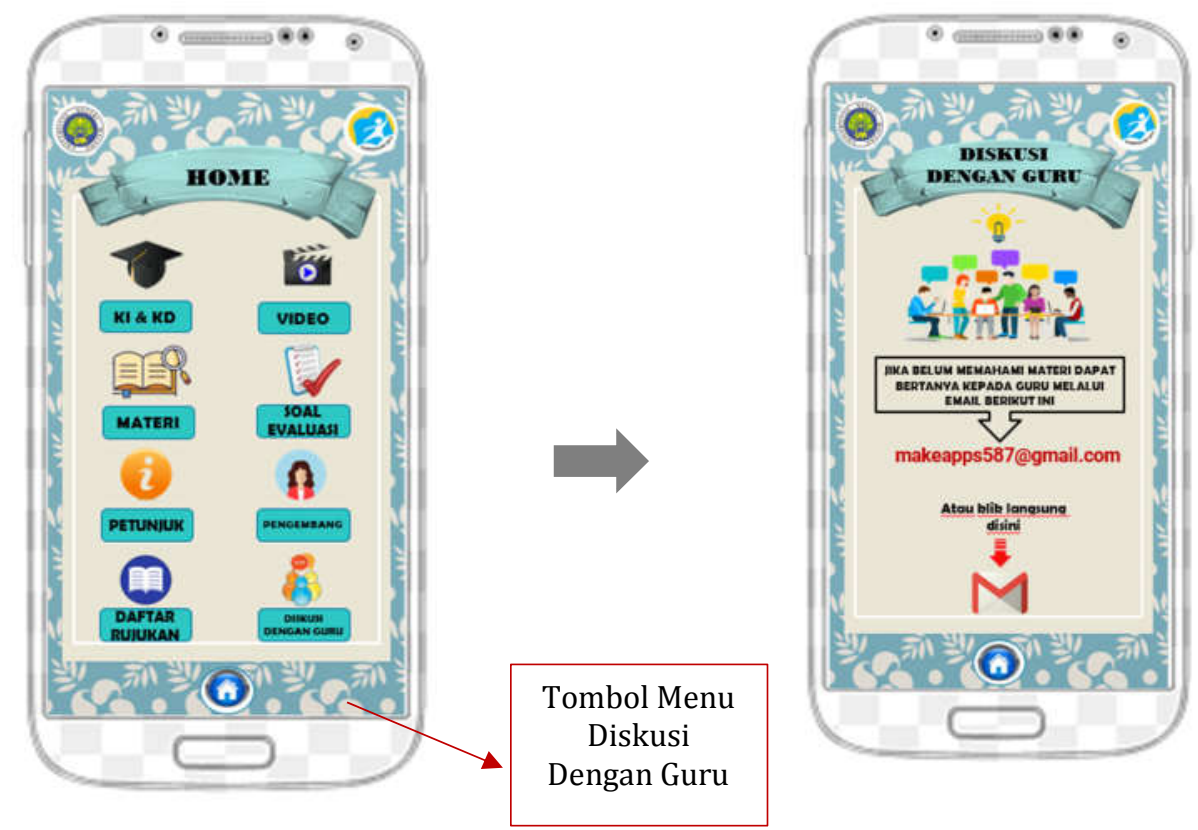

Gambar 4. Tampilan menu diskusi dengan guru 
Tampilan media pembelajaran mobile learning MAKE-APPS secara umum dapat dilihat pada Gambar 5 berikut ini:
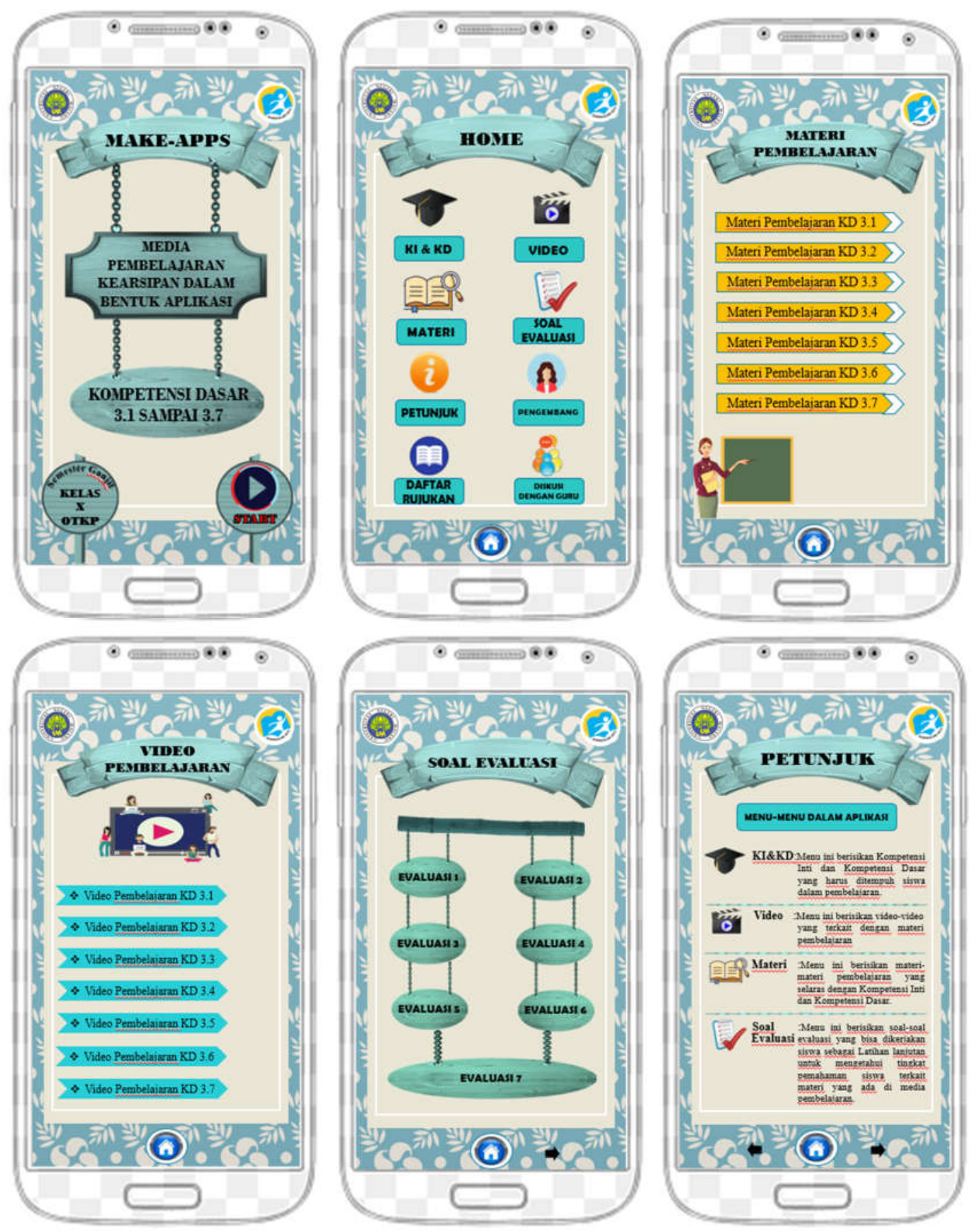

Gambar 5. Tampilan media pembelajaran mobile learning MAKE-APPS secara umum 


\section{Simpulan}

Penelitian dan pengembangan ini menghasilkan media pembelajaran mobile learning berbasis android pada mata pelajaran kearsipan untuk kelas X OTKP di SMK Muhammadiyah 5 Kepanjen Malang. Media pembelajaran ini bernama MAKE-APPS yang dapat diinstall pada smartphone peserta didik masing-masing.

Media pembelajaran pada penelitian ini telah dinyatakan 'Sangat Valid' dan layak digunakan dalam pembelajaran kearsipan melalui validasi oleh ahli media dan ahli materi. Media pembelajaran ini juga memungkinkan pembelajaran kapanpun dan dimanapun, bahkan secara mandiri tanpa harus terkait dengan kegiatan tatap muka di sekolah.

Media pembelajaran mobile learning MAKE-APPS ini hanya terfokus pada beberapa kompetensi dasar dan terbatas pada sistem operasi android, sehingga diharapkan peneliti selanjutnya dapat mengembangkan media pembelajaran pada sistem operasi iOS dan menyajikan media pembelajaran pada kompetensi dasar lainnya.

\section{Ucapan Terima Kasih}

Penulis mengucapkan terimakasih kepada Universitas Negeri Malang dan SMK Muhammadiyah 5 Kepanjen Malang yang telah memfasilitasi dan memberi izin kepada peneliti untuk melakukan kegiatan penelitian dan pengembangan ini

\section{Daftar Rujukan}

Alhafidz, M.R.L., Haryono, A., (2018). Pengembangan Mobile Learning Berbasis Android Sebagai Media Pembelajaran Ekonomi. J. Pendidik. Ekon. 11, 118-124. https://dx.doi.org/10.17977/UM014vl Ii22018p0107

Barnacki, M.L., Greene, J.A., Crompton, H., (2020). Mobile technology, learning, and archievement: Advances in understanding and measuring the role of mobile technology in education. Contemp. Educ. Psychol. 60, 101827. https://doi.org/10.1016/j.cedpsych.2019. 101827

Buabeng-Andoh, C. (2012). Factors Influencing Teachers Adoption and Integration of Information and Communication Technology into Teaching: A Review of the Literature. International Journal of Education and Development Using ICT, 8(1), 136-155.

Buyukbaykal, C. I. (2015). Communication Technologies and Education in The Information Age. Procedia Social and Behavioral Sciences, 174, 636-640. doi: 10.1016/j.sbspro.2015.01.594

Cahyana, U., Paristowati, M., Fauziah, S., (2018). Development of Android-Based Mobile learning media on Atomic Structure and Periodic Table. IOP Conf Ser. Mater. Sci. Eng. 434, 012095. https://doi.org/10.1088/1757-899X/434/1/012095

Fajriah, U. N., \& Churiyah, M. (2016). Utilizing Instructional Media for Teaching Infrastructure Administration. Journal of Education and Practice, 7(6), 100-111.

Hrynko, V., (2019). Electronic Social Networking Sites As A Universal Tool For Developing Future Teachers' Digital Competence. Journal Advanced Education.

Irawan, C., \& Djamika, E. T. (2018). Developing Instructional Media Mobile Learning Based Android to Improve Learning Outcomes. Jurnal Pendidikan Bisnis Dan Manajemen, 4(3), 117-124. doi: 10.17977/um003v4i32018p117

Irawan, C., Rww, E.T.D., (2018). Developing Instructional Media Mobile Learning Based Android to Improve Learning Outcomes. JPBM J. Pendidik. Bisnis Dan Manaj. 4, 107-113. https://doi.org/10/17977/um003v4i32018p117

Khairani, Majidah, (2016). Pengembangan Media Pembelajaran Dalam Bentuk Macromedia Flash Materi Tabung Untuk Smp Kelas Ix. Jurnal Iptek Terapan.

Khomaruddin, A.N., Efriyanti, L., (2018). Pengembangan Media Pembelejaran Mobile Learning Berbasis Android Pada Mata Kuliah Kecerdasan Buatan. J. Educ. J. Stund. 3, 72-87. https://doi.org/10.30983/educative.v3il.543 
Liliarti, N., Kuswanto, H., (2018). Improving the Competence of Diagrammatic and Argumentative Representation in Physics through Android-Based Mobile Learning Application. Int. J. Instr. 11, 107122.

Lubis, I. R., \& Ikhsan, J. (2015). Pengembangan Media Pembelajaran Kimia Berbasis Android untuk Meningkatkan Motivasi Belajar dan Prestasi Kognitif Peserta Didik SMA. Jurnal Inovasi Pendidikan IPA, 1(2), 191-201. doi: 10.21831/jipi.v1i2.7504

Mastumasari, I., Wasiti, \& Sulistyaningsih. (2017). Improving Learning Outcomes in Office Automation Subjects Through Development of Video-Based Media Learning Operating Microsoft Publisher 2010. JPBM (Jurnal Pendidikan Bisnis Dan Manajemen), 3(1), 55-64. doi: 10.17977/um003v3i12017p055

Muyaroah, S., Fajartia, M., (2017). Pengembangan Media Pembelajaran Berbasis Android dengan menggunakan Aplikasi Adobe Flash CS 6 pada Mata Pelajaran Biologi 5.

Nurrita, T. (2018). Pengembangan media pembelajaran untuk meningkatkan hasil belajar siswa. MISYKAT: Jurnal Ilmu-ilmu Al-Quran, Hadist, Syari'ah dan Tarbiyah, 3(1), 171-210.

Nurwijayanti, A., Budiyono, \& Fitriana, L. (2019). Combining Google SketchUp and Ispring Suite 8: A Breakthrough to Develop Geometry Learning Media. Journal on Mathematics Education, 10(1), 103116.

Praseptiawan, M., Sujana, D., Djuanda, M., (2018). Pengembangan Mobile Learning (M-Learning) Stkip Setiabudhi Sebagai Daya Dukung Pembelajaran Mahasiswa. Produktif J. Ilm. Pendidik. Teknol. Inf. 2, 1318.

Purwanto, P., Ramadhan, A.N., (2017). Pengembangan dan Unjuk Kerja Sistem Kearsipan Elektronik PSPAP. Efisiensi - Kajian Ilmu Administrasi 13, 31-65. https://doi.org/10.21831/efisiensi.v13i2.11676

Rahmat, RF., Mursyida, L., Rizal, F., Krismadinata, K., Yunus, Y., (2019). Pengembangan media pembelajaran berbasis mobile learning pada mata pelajaran simulasi digital. J. Inov. Teknol. Pendidik. 6, 116-126. https://doi.org/10.21831/jtip.v6i2.27414

Ramdhani, M. A., \& Muhammadiyah, H. (2015). The Criteria of Learning Media Selection for Character Education in Higher Education. 174-182. Retrieved from http://digilib.uinsgd.ac.id/5118/

Sari, N.I., Sulur, S., Pramono, N.A., (2020). Pengembangan M-Learning Physics for Fun Berbasis Android pada Materi Listrik Statis untuk Siswa SMA/MA. J. Ris. Pendidik. Fis. 4, 13-17. https://doi.org/10.17977/um058v4ilp13-17

Siregar, U.A., Hadi, W., \& Daulay. S. (2017). The Development of Procedure Text Learning Media in The Form of Animation for Student of Class VII in SMP/MTS. Journal of Education and Practice. Vol.8, No.35.

Suprianto, A., Ahmadi, F., Suminar, T., (2019). The Development of Mathematics Mobile Learning Media to Improve Students' Autonomous and Learning Outcomes. J. Prim Educ. 8,84-91.

Taufiq, M., Amalia, A. V., Parmin, P., (2017). The Development Of Science Mobile Learning With Convervation Vision Based On Android App Inventor 2. Unnes Sci. Educ. J. 6. https://doi.org/10.15294/usej.v6il.13179

Ulfa, A. M., Sugiyarto, K. H., \& Ikhsan, J. (2017, May). The effect of the use of android-based application in learning together to improve students' academic performance. In AIP Conference Proceedings (Vol. 1847, No. 1, p. 050008). AIP Publishing LLC.. doi: 10.1063/1.4983910 